\title{
The Effects of The Presence of Tutor in The Learning Video on Cognitive Load and Academic Achievement
}

\author{
Weni Anggraini $^{1 *}$, Sunawan Sunawan ${ }^{1}$, Ali Murtadho \\ Universitas Negeri Semarang, Indonesia ${ }^{1}$ \\ Universitas Islam Negeri Walisongo Semarang, Indonesia² \\ @wenianggraini@students.unnes.ac.id*
}

Abstract

This study was intended to determine the effect of the presence of tutors in the learning video on cognitive load and academic achievement. The design used in this study was the posttest control group design. The subjects of this study were 30 students of eleventh-grade science of senior high school number 1 Ungaran. The measurements of the data were

Article Information:

Received December 13, 2019

Revised December 14, 2019

Accepted December 16, 2019

Keywords: learning video; cognitive load; academic achievement carried out using cognitive load questionnaires, eye-tracking measurements, and biological matter of reproductive materials (prior knowledge and posttest teaching). The result of analysis using the Multivariate analysis of variance test showed that the presence of tutors in the learning video did not have a significant effect on extraneous load $(F(2.27)=2.6, p>0.05)$, the presence of tutors in the learning video did not have a significant effect on germane load in the subjective measurements $(F(2.27)=0.06, p>0.05)$, however, the presence of tutors in the learning video has a significant effect on the objective measurements $(F(2.27)=24.47, p<0.05)$ and $(F(2.27)=28.14, p<0.05)$. Furthermore, the presence of tutors in the learning video has a significant effect on academic achievement with $(F(2.27)=3.38, p<0.05)$. The findings of this study proved that there were effects of the presence of tutor in the learning video on germane load and academic achievement.

\section{INTRODUCTION}

Guidance and counseling for students to become individuals who can develop their full potential. Guidance and counseling are very important. Guidance and counseling have four fields, that is personal, social, learning and career guidance (Prayitno \& Amti, 2004). Learning guidance is a tutoring service that allows students to develop themselves, good attitudes and study habits, as well as various aspects of learning objectives and other activities (Willis, 2004). Learning guidance aims to help students develop learning abilities to follow levels and educational paths and to master a particular skill. Learning guidance services provided by counselors will open space for students to solve the problems encountered in the learning process and be able to achieve the objectives of learning. In the modern era, the demands of independent learning are also formulated in the curriculum that requires students to experience firsthand learning. Thus, learning guidance is needed to explore one's potential, attitudes in learning, motivation and appropriate learning strategies that can increase knowledge in a fun way.

Currently, an interesting learning media to be used in learning is a video which has various benefits compared to other media. Therefore the development of student learning

How to cite:

E-ISSN:

Published by:
Anggraini, W., Sunawan, S., \& Murtadho, A. (2019). The Effect of The Presence of Tutor in The Learning Video on Cognitive Load and Academic Achievement. Islamic Guidance and Counseling Journal, 3(1). https://doi.org/10.25217/igcj.v3i1.656 2614-1566

Institut Agama Islam Ma'arif NU (IAIMNU) Metro Lampung 
strategies must always be improved. The counselor must be able to answer the challenges in dealing with problems experienced by students in the process of seeking knowledge independently. And in the end, the existence of learning guidance provided by counselors is very important for student development. According to Hastuti \& Winkel (2006), the counselor must have extensive knowledge about learning activities. Therefore, counselors need to know the various types of learning videos that influence the cognitive load and academic achievement of students.

Academic achievement is an important issue in learning activity. York, Gibson, \& Rankin (2015) states that academic achievement is an instrument to measure the quality of students' academic work in the form of special values. Increasing academic achievement is a special concern of various parties involved in the learning process. Thus, students are expected to be able to achieve educational goals by having high academic achievement. Academic achievement is a benchmark that can be calculated accurately to know the success of education and achievement of goals and can be an evaluation of the learning process. This is consistent with the opinion of the Ministry of Education Minessota (2017) which states that the importance of knowing academic achievement is to identify students' adoption of predetermined standards and be an evaluation material for schools in providing support to students. If the majority of students' academic achievement is in a low position, then this can be an initial indicator that there has been an error in the learning process. Academic achievement can be measured when students have followed the learning process. In the learning process, information processing occurs which can influence students' knowledge. In information processing, there is an important issue, called a cognitive load.

Cognitive load is the process of transferring information from the working memory (short term) to the long term memory (de Jong, 2010; John Sweller, 2005). According to Sweller, Ayres, \& Kalyuga (2011), cognitive load is divided into 3 components, they are: 1) Intrinsic cognitive load, namely the burden that comes from the complexity of a learning material; 2) Extraneous load, which is the burden that comes from the way the presentation of a learning material; 3) Germane load, which is a cognitive content that comes from the cognitive processes to understand the learning material. Extraneous load is an effort imposed by instructional, design and presentation activities (Sweller, 1999). The high extraneous load harms information processing, the processing of information that is not relevant to the learning process. This is following the opinion of Kizilcec, Bailenson, \& Gomez (2015), students do not fully understand the content when they have to divide attention between hearing and visual media, such as videos with tutor voice and text. The high extraneous load will make the germane load unable to work optimally. Germane load is the result of students' motivational efforts used to build schemes and produce positive learning experiences and store them on the long-term memory (de Jong, 2010). van Merriënboer \& Sweller (2005) germane load is the process of processing, construction, and automation of schemes in students. Germane load is an element of cognitive load that is positive when in an optimal position. Following the opinion of Cierniak, Scheiter, \& Gerjets (2009), the germane load is the only element in cognitive load theory where a high level is considered positive for the learning experience.

The learning process can be done using the learning media. The presence of video media as a learning medium has influenced the learning process. This is in line with the results of research by Mohamed, Yousef, Chatti, \& Schroeder (2014) which shows that videobased learning produces diverse learning outcomes. The diversity of the learning outcomes from the use of learning videos can occur due to the various types of displays and presentations in the learning process. This can be seen from Sabtono \& Purnomo's (2015) research stating that there is an influence of the use of instructional video media on students' academic achievement. Homer, Plass, \& Blake (2008) state that learning videos have a 
positive effect on cognitive load. However, Hong, Pi, \& Yang (2018) stated that video lectures (live videos or tutors in the video) have a high extraneous load on procedural learning. Currently, many choices can be made by instructional designers when creating video-based learning content. For example, by adding a teacher figure to the video or showing slides and audio explanations. With the increasing number of types of learning videos that can be made, it is necessary to clarify the appropriate types and patterns of videos which can improve the academic performance and have a low extraneous load and be able to optimize the germane load.

Based on the results of research conducted by Colliot \& Jamet (2018) shows that the presence of a teacher (face and gestures) positively influences students' motivation and involvement in their learning. This study only limited to one type of video that has a teacher in the upper corner of the screen and cognitive load measurements that only measure extraneous loads. Therefore, it is recommended for future researchers to examine the effects of teacher characteristics (tutors or instructors) shown on the screen more specifically and to measure other aspects of cognitive load. Therefore, in this case, the researcher tries to clarify and generalize which types of videos affect the performance of students who focus on the presence of tutors in the video and expand on the cognitive load component namely germane load. In this study, the learning also conducted with the type of video without a tutor and also the text. Based on the explanation above, this study was conducted to examine the effect of the presence of tutors in the learning video on student cognitive load and academic achievement.

\section{METHODS}

This study only applied a posttest control group design involving 30 students of eleventh-grade science of senior high school number 1 Ungaran. There are 3 groups in the study consisting of 10 students. The first group obtained a learning video with a small human tutor in the lower-left corner (Figure 1); the second group obtained a learning video without tutor (Figure 2); group 3 is a control group that obtained material in the form of text (Figure $3)$. The learning material used as the research material was biological material in the reproduction sub material. The video duration was 14 minutes 25 seconds. The text used was the material on which the video was made.

The data collection on cognitive load was carried out using a cognitive load questionnaire developed by Leppink, Paas, van Gog, van der Vleuten, \& van Merriënboer (2014). Since the cognitive load questionnaire still uses English, this instrument was presented in Indonesian using a back-translation. This questionnaire consists of 14 items, however, in this study only 9 items that were used in the questionnaire (4 items=extraneous load, 5 items=germane load), one of the statements was "the explanation in learning is very unclear". This instrument applied 7 scales ( $1=$ very low to $7=$ very high). The reliability level of the extraneous load questionnaire was 0.826 and germane load questionnaire was 0.778 , both of them included in the strong category.

The data on cognitive load was objectively carried out by measuring eye-tracking (Figure 4). The instrument used in this study was the Tobii eye-track T60 (Stockholm, Sweden) which is embedded in a 19-inch TFT monitor with a maximum resolution of $1920 \times 1080$ pixels. This eye tracker operates at a $60-\mathrm{Hz}$ sampling rate and has a spatial resolution of below 0.5 . Then, the academic achievement data collection was done by giving questions about the learning material in the video which is about reproduction which consists of 19 question items. During the process of the study, respondents were asked to watch and study videos according to video duration, whereas, the control group was given the opportunity of time according to the respondents' needs. The data analysis using statistical tests Multivariate Analysis of variance (MANOVA) using the help of statistical packages for 
the social science 25 to see the effect of the existence of tutors on cognitive load and academic achievement.

The procedures in this study were: a) The subjects of the study were instructed regarding the implementation of the study. They were asked to learn the learning video that has been prepared. The first experimental group which consists of 10 students obtained a video with the presence of a tutor in the bottom corner of the left. The second group which consists of 10 students obtained videos without a tutor. And the third group which consists of 10 students obtained text material on the monitor layer; b) The subjects of the study in groups 1 and 2 did a learning activity through the video that has been prepared for 14 minutes 43 seconds, whereas, group 3 was given time as needed while reading the material provided. During the study, the eye movement of the subjects of the study was measured using eyetracking; c) The subjects of the study completed the cognitive load questionnaires and academic achievement post-tests.

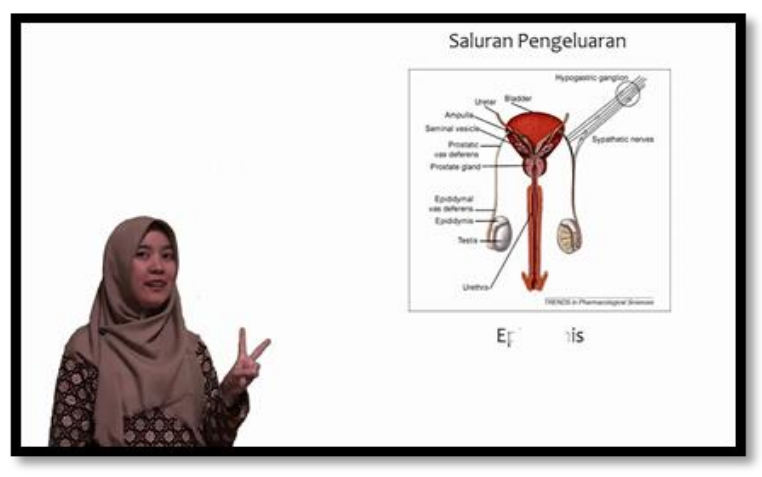

Figure 1

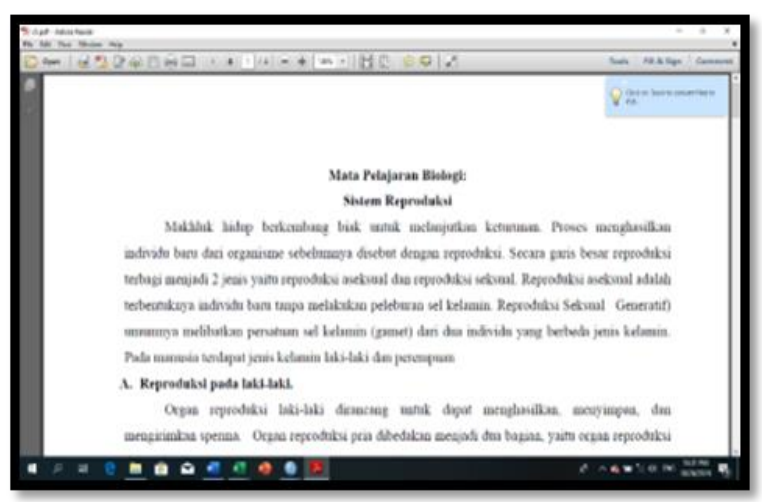

Figure 3

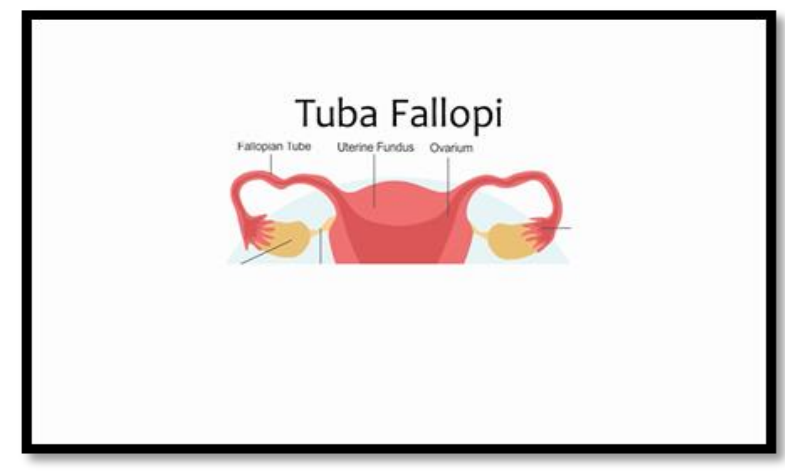

Figure 2

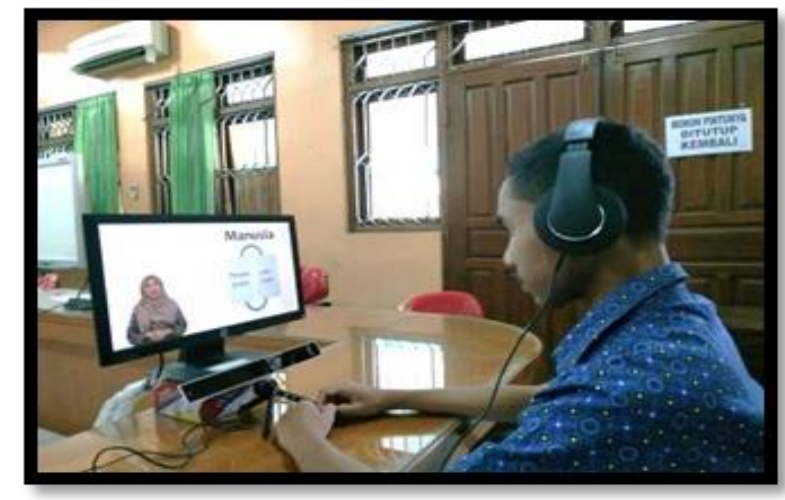

Figure 4

\section{RESULTS AND DISCUSSION}

Based on the results of the description of the data, it can be seen in Table 1 that the condition of students' extraneous load based on the average count, the group that tends to have extraneous load in the low category was group $1(M=9, S D=3.71)$, whereas, group $2(M=10.5$, $\mathrm{SD}=4.21)$ and group $3(\mathrm{M}=12.5, \mathrm{SD}=2.17)$ have an extraneous load which belongs to the moderate category. Then, it can be seen that the germane load of students with subjective measurements using a questionnaire based on the average count, group 1 was $(M=26.5$, $\mathrm{SD}=2.64)$, group 2 was $(\mathrm{M}=26.1, \mathrm{SD}=5.26)$, group 3 was $(\mathrm{M}=25.9, \mathrm{SD}=3.25)$, all groups have a tendency in the high category. Furthermore, the objective measurements of germane load can be seen from the duration and frequency of the fixation made by the subject of the study to the material (relevant information). Based on the data description, it can be interpreted that the average duration of fixation in the material in group 1 tends to be in the moderate category 
$(\mathrm{M}=471.38, \mathrm{SD}=117.3)$, group 2 tends to be in the high category $(\mathrm{M}=614.19, \mathrm{SD}=86.46)$, group 3 tends to be in the moderate category $(\mathrm{M}=300.38, \mathrm{SD}=95.34)$. Then, the average frequency of fixation group $1(M=1424.6, S D=331.1)$, group $2(M=1752.8, S D=206.1)$, group $3(\mathrm{M}=855.1, \mathrm{SD}=261.2)$. The highest duration of fixation was in group 2. The data description shows that the average academic achievement of group 1 was $(\mathrm{M}=16.7, \mathrm{SD}=1.34)$, group 2 $(\mathrm{M}=16, \mathrm{SD}=1.05)$, group $3(\mathrm{M}=14.8, \mathrm{SD}=2.3)$. All groups tend to have high academic achievement, and the highest was indicated by group 1 .

The results of the test that have been done can be seen in Table 2, which shows that there is no significant effect of various types of learning videos on the extraneous load $(\mathrm{F}(2.27)=2.61, \mathrm{p}>0.05$. There is no significant effect from various types of learning videos on the germane load $(\mathrm{F}(2.27)=0.06, \mathrm{p}>0.05$. There is a significant effect of various types of learning videos on the Academic Achievement $(\mathrm{F}(2.27)=3.38, \mathrm{p}<0.05$. There is a significant effect of various types of learning videos on the fixation duration on the material $(\mathrm{F}(2.27)=24.46, \mathrm{p}<0.05$. There is a significant effect of various types of learning videos on the fixation frequency in the material $(\mathrm{F}(2.27)=28.14, \mathrm{p}<0.05$.

\begin{tabular}{lcccccccc}
\hline Variable & \multicolumn{2}{c}{1} & \multicolumn{2}{c}{2} & \multicolumn{2}{c}{3} & \multicolumn{2}{c}{ Total } \\
\cline { 2 - 9 } & Mean & SD & Mean & SD & Mean & SD & Mean & SD \\
\hline Extraneous load & 9 & 3.71 & 10.5 & 4.12 & 12.5 & 2.17 & 10.67 & 3.62 \\
Germane load & 26.5 & 2.64 & 26.1 & 5.26 & 25.9 & 3.25 & 26.16 & 3.75 \\
$\begin{array}{l}\text { Duration of fixation to the } \\
\text { material }\end{array}$ & 471,38 & 117,3 & 614,19 & 86,46 & 300 & 95,34 & 461.88 & 162.69 \\
$\begin{array}{l}\text { Frequency of fixation to } \\
\text { the material }\end{array}$ & 1424,6 & 331,1 & 1752,8 & 206,1 & 855,1 & 261,2 & 1344.5 & 459.3 \\
Academic Achievement & 16,7 & 1,34 & 16 & 1,05 & 14,8 & 2,3 & 15.83 & 1.78 \\
\hline & \multicolumn{7}{c}{ Table 1. Description of research data } \\
\end{tabular}

\begin{tabular}{lccc} 
Dependent variable & F & Df & P \\
Extraneous load & 2.6 & 2,27 & $>0,05$ \\
Germane load & 0.06 & 2,27 & $>0,05$ \\
Duration of fixation to the material & 24.47 & 2,27 & $<0,05$ \\
Frequency of fixation to the material & 28.14 & 2,27 & $<0,05$ \\
Academic Achievement & 3.38 & 2,27 & $<0,05$ \\
\hline
\end{tabular}

Table 2. Tests of Between-Subjects Effects

Then, a comparison between groups on variables that have a significant effect was done. The comparisons between groups can be seen in Table 3 .

\begin{tabular}{lcccc}
\hline Dependent variable & Group & MD & SE & $p$ \\
\hline Duration of fixation to the material & $1-2$ & -142.8 & 44.9 & $<0,05$ \\
& $1-3$ & 171.3 & 44.9 & $<0,05$ \\
Frequency of fixation to the material & $2-3$ & 314.1 & 44.9 & $<0,05$ \\
& $1-2$ & -329.2 & 121.2 & $<0,05$ \\
Academic Achievement & $1-3$ & 569.5 & 121.2 & $<0,05$ \\
& $2-3$ & 898.7 & 121.2 & $<0,05$ \\
& $1-2$ & 0.7 & 0.73 & $>0,05$ \\
& $1-3$ & 1.9 & 0.73 & $<0,05$ \\
& $2-3$ & 1.2 & 0.73 & $>0,05$ \\
\hline
\end{tabular}

Table 3. The Test of post hoc using Bonferroni Technique 
Table 3 shows that there were no significant academic achievement differences between groups 1 and 2 ( $\mathrm{MD}=0.7, \mathrm{p}>0.05)$, there were significant academic achievement differences between groups 1 and $3(\mathrm{MD}=1.9, \mathrm{p}<0.05)$, there is no significant academic achievement difference between groups 2 and $3(\mathrm{MD}=1.2, \mathrm{p}>0.05)$. Then it was found that there were significant differences in germane load (duration of fixation on material) between groups 1 and $2(\mathrm{MD}=-142.8, \mathrm{p}<0.05)$, there were significant differences in Germane load (duration of fixation on material) between groups 1 and $3(\mathrm{MD}=171.3, \mathrm{p}<0.05)$, there was a significant difference in Germane load (duration of fixation on the material) between groups 2 and 3 $(\mathrm{MD}=314.1, \mathrm{p}<0.05)$. It was further noted that there were significant differences in germane load (frequency fixation on material) between groups 1 and $3(\mathrm{MD}=-329.2, \mathrm{p}<0.05)$, there were significant differences in germane load (frequency fixation on material) between groups 1 and $2(\mathrm{MD}=569.5, \mathrm{p}<0.05)$, and there is a significant difference in germane load (fixation frequency on material) between groups 2 and $3(\mathrm{MD}=898.7, \mathrm{p}<0.05)$.

This shows that there is no effect of the presence of a tutor in a learning video on extraneous load. In other words, there is no interference effect on the type of video in the experiments conducted. It can be interpreted that the presence of tutors in the video does not distract students from the relevant information and does not inhibit synchronous information processing. This is in line with the research conducted by Colliot \& Jamet (2018) which states that there is no effect of video in the form of tutors and audio on the cognitive load (extraneous load) of students when conducting the learning. In this study, there were 2 types of videos, videos with tutors in the upper left corner and videos without tutors. However, contrary to research by Mayer \& Moreno (1998) which states that using video lectures recorded online and accompanied by presentation slides is not ideal for the learning, this happens since it will divide the student attention between the speaker and the information displayed and will ultimately present separate attention effects.

Based on the results of the study, it can be determined that the presence of tutors in the learning video does not significantly influence the germane load of students on subjective measurements, however, it has a significant effect on the objective measurements (the measurement of duration and frequency of fixation). Although subjectively there are no differences in the students making an effort to learn a learning material that is presented, objectively through attention through vision, it turns out that students make different efforts in processing information according to the type of delivery and presentation of information presented. This can happen since it is subjective or under the feeling of every student who is in the process of education has a developmental task to learn. Thus, in the learning process, every student has been required to understand every material in the learning and have become accustomed to doing the learning endeavors. Then, it was objectively indicating that the efforts made by students in the learning process have a significant influence. This shows that student attention in the learning process which was indicated by the level of fixation or student focus on the learning material presented has a significant effect.

Based on the presence of tutors presented in the learning video, it can be seen that the fixation on the most material is in the type of video without the tutor, whereas, the video with the presence of a tutor has a lower duration of fixation. This indicated that the presence of tutors in the learning video can be extraneous load. This is under the opinion of Costley \& Lange (2018) that the high level of extraneous load is generally considered to be detrimental to the germane load, and conversely, the extraneous load can be beneficial to the germane load. This has a slight difference with the results of research conducted by Colliot \& Jamet (2018) showing that the presence of a teacher (face and gestures) positively influences students' motivation and involvement in their learning. Compared to the research conducted by Colliot \& Jamet (2018) this research succeeded in proving that the use of tutors in the learning video can affect the German load of students. 
Furthermore, the results of the study indicated that the presence of tutors in the learning video can influence the students' academic achievement. This is in line with the research conducted by Sabtono \& Purnomo (2015) which states that there is an influence of the use of instructional video media on student achievement. This may occur due to a large number of senses used when receiving information when conducting the learning process (Azhar, 2007). The processing of relevant information also affects this study which can be seen from the highest academic achievement in the video with the tutor and the video without the tutor. This happened due to the processing of relevant information so that students can form schemes in their cognitive processes and can transfer information from the short term memory to the long term memory. Finally, when students are faced with questions about the video they have learned, students will easily remember the answers to these questions according to the memories they have stored in the long term memory.

Although this study has been able to prove the influence of the presence of tutors in learning videos on students' cognitive load and academic achievement, this study still focuses on the cognitive realm. Therefore, further research is expected to be able to measure the emotions of the students when they receiving learning videos with various types of tutors.

\section{CONCLUSIONS}

Based on the description of the findings, it can be concluded that the presence of a tutor in the learning video does not affect the extraneous load of students eleventh-grade science of senior high school number 1 Ungaran. The existence of a tutor in the learning video does not affect the German load on subjective measurements, however, it influences the objective measurement of students' eleventh-grade science of senior high school number 1 Ungaran. Besides, the presence of tutors in the learning video affects the academic achievement of students eleventh-grade science of senior high school number 1 Ungaran. Videos that have the most optimal germane load are videos without tutors.

\section{ACKNOWLEDGMENTS}

The author expresses their sincere thanks to Dr. Awalya, M.Pd., Kons. for the supervision of research and adaptation of research instruments. Supriyanto, S.Pd. as the principal of Senior High School number 1 Ungaran who has permitted the authors to carry out the research.

\section{AUTHOR CONTRIBUTION STATEMENTS}

WA designs research implementation, data collection, and interventions at the research location. SN and AM provide direction as well as assisting in the preparation of research designs and supervision during the research carried out on site.

\section{REFERENCES}

Azhar, A. (2007). Media pembelajaran. Retrieved from Google Scholar

Cierniak, G., Scheiter, K., \& Gerjets, P. (2009). Explaining the split-attention effect: Is the reduction of extraneous cognitive load accompanied by an increase in germane cognitive load? Computers in Human Behavior, 25(2), 315-324. https://doi.org/10.1016/j.chb.2008.12.020

Colliot, T., \& Jamet, É. (2018). Understanding the effects of a teacher video on learning from a multimedia document: An eye-tracking study. Educational Technology Research and Development, 66(6), 1415-1433. https://doi.org/10.1007/s11423-018-9594-x 
Costley, J., \& Lange, C. (2018). The Moderating Effects of Group Work on the Relationship Between Motivation and Cognitive Load. The International Review of Research in Open and Distributed Learning, 19(1). https://doi.org/10.19173/irrodl.v19i1.3325

de Jong, T. (2010). Cognitive load theory, educational research, and instructional design: Some food for thought. Instructional Science, 38(2), 105-134. https://doi.org/10.1007/s11251-009-9110-0

Hastuti, S., \& Winkel, W. S. (2006). Bimbingan dan konseling di institusi pendidikan. Jakarta: Grasindo. Retrieved from Google Scholar

Homer, B. D., Plass, J. L., \& Blake, L. (2008). The effects of video on cognitive load and social presence in multimedia-learning. Computers in Human Behavior, 24(3), 786797. https://doi.org/10.1016/j.chb.2007.02.009

Hong, J., Pi, Z., \& Yang, J. (2018). Learning declarative and procedural knowledge via video lectures: Cognitive load and learning effectiveness. Innovations in Education and Teaching International, 55(1), 74-81. https://doi.org/10.1080/14703297.2016.1237371

Kizilcec, R. F., Bailenson, J. N., \& Gomez, C. J. (2015). The instructor's face in video instruction: Evidence from two large-scale field studies. Journal of Educational Psychology, 107(3), 724-739. https://doi.org/10.1037/edu0000013

Leppink, J., Paas, F., van Gog, T., van der Vleuten, C. P. M., \& van Merriënboer, J. J. G. (2014). Effects of pairs of problems and examples on task performance and different types of cognitive load. Learning and Instruction, 30, 32-42. https://doi.org/10.1016/j.learninstruc.2013.12.001

Mayer, R. E., \& Moreno, R. (1998). A split-attention effect in multimedia learning: Evidence for dual processing systems in working memory. Journal of Educational Psychology, 90(2), 312-320. https://doi.org/10.1037/0022-0663.90.2.312

Minessota, M. of E. (2017). Academic Achievement. Retrieved from Google Scholar

Mohamed, A., Yousef, F., Chatti, M. A., \& Schroeder, U. (2014). Video-Based Learning: A Critical Analysis of The Research Published in 2003-2013 and Future Visions. The Sixth International Conference on Mobile, Hybrid, and On-Line Learning. Presented at the The Sixth International Conference on Mobile, Hybrid, and On-line Learning. Retrieved from Google Scholar

Prayitno, E. A., \& Amti, E. (2004). Dasar-dasar bimbingan dan konseling. Jakarta: Rineka Cipta. Retrieved from Google Scholar

Sabtono, W., \& Purnomo, E. (2015). Pengaruh Penggunaan Video Pembelajaran Terhadap Prestasi Praktik Pemesinan di SMK Muhammadiyah Prambanan. Jurnal Pendidikan Vokasional Teknik Mesin, 3(7), 511-518. Retrieved from Google Scholar

Sweller, J. (1999). Instructional design in technical areas. Camberwell. Victoria: ACER Press. Retrieved from Google Scholar

Sweller, John. (2005). Implications of cognitive load theory for multimedia learning. The Cambridge Handbook of Multimedia Learning, 19-30. Retrieved from Google Scholar

Sweller, John, Ayres, P., \& Kalyuga, S. (2011). Cognitive Load Theory. https://doi.org/10.1007/978-1-4419-8126-4

van Merriënboer, J. J. G., \& Sweller, J. (2005). Cognitive Load Theory and Complex Learning: Recent Developments and Future Directions. Educational Psychology Review, 17(2), 147-177. https://doi.org/10.1007/s10648-005-3951-0

Willis, S. S. (2004). Konseling individual teori dan praktek. Bandung: Alfabeta, 79. Retrieved from Google Scholar

York, T. T., Gibson, C., \& Rankin, S. (2015). Defining and Measuring Academic Success. Practical Assessment, Research \& Evaluation, 20(5), 21. Retrieved from Google Scholar 
Copyright holder :

(c) Anggraini, W., Sunawan, S., \& Murtadho, A. (2020)

First publication right :

(C) Islamic Guidance and Counseling Journal

This article is licensed under:

\section{CC-BY-SA}

